\title{
Keragaan Tanaman Kacang Tanah Pasca Serangan Hama Kutu Kebul Bemisia Tabaci Genn
}

\author{
Peanut Plant Performance after Whitefly Attack Bemisia tabaci Genn
}

\author{
Kurnia Paramita Sari ${ }^{1}$, Nurul Aini ${ }^{2}$, Bambang Tri Rahardjo ${ }^{3}$ \\ ${ }^{1}$ Balai Penelitian Tanaman Aneka Kacang dan Umbi \\ ${ }^{2,3}$ Fakultas Pertanian, Universitas Brawijaya
}

\section{ARTICLE INFO}

Article history:

DOI:

$\underline{10.30595 / p s p f s . v 2 i .196}$

Submitted:

July 29, 2021

Accepted:

Sept 10, 2021

Published:

Nov 10, 2021

Keywords:

Peanuts, Whitefly, Plant

Performance

\begin{abstract}
Peanut is one of the plants that are widely cultivated by farmers. Biotic and abiotic stresses are one of the barriers to peanut productivity. The biotic attack of the whitefly Bemisia tabaci infestation on peanuts impacts the performance of the plant itself. The purpose of this study was to determine the performance of peanut plants after being attacked by whiteflies. The research was carried out in 2019 using 10 peanut genotypes arranged according to a completely randomized design and repeated three times. The research plants were infested with whitefly and then observed several characters, including the number of flowers, number of gynophores, number of branches, number of roots, root length, plant height, number and weight of pods, number and weight of seeds, and crop yield index. The results showed that the groundnut infested with whitefly contained sooty dew as a direct insect attack. The population and sooty dew caused the number of flowers and branches to be low, the value of the number of dry pods and dry pod weight was low, the dry seed weight was low, and the crop harvest index was also low.
\end{abstract}

This work is licensed under a Creative Commons Attribution 4.0 International License.

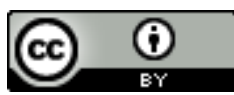

Corresponding Author:

Kurnia Paramita Sari

Balai Penelitian Tanaman Aneka Kacang dan Umbi

J1.Raya Kendalpayak KM.8 KP 66 Pakisaji Malang

Email: balitkabi@litbang.pertanian.go.id

\section{PENDAHULUAN}

Kacang tanah merupakan salah satu bahan industri makanan, sehingga komoditas ini banyak dikembangkan oleh petani. Dalam budidaya kacang tanah terdapat beberapa kendala yang dihadapi baik faktor biotik maupun abiotik. Salah satu faktor biotik adalah serangan organisme pengganggu tanaman (OPT) berupa hama atau penyakit.

Hama kacang tanah dikategorikan menjadi dua jenis,yaitu hama daun dan hama polong. Hama daun utama yang mengakibatkan penurunan produksi adalah Thrips, hama ini merupakan vector virus dari TSWV (Al-Saleh et al., 2007; Branch and Brenneman, 2015; Lassiter et al.,2016). Di negara-negara penghasil kacang tanah , serangan nematoda menjadi salah satu factor penurunan produksi (Lassiter et al.,2016). Selain dua hama tersebut, terdapat hama yang berperang sebagai vector virus sehingga menyebabkan penurunan hasil yaitu kutu kebul Bemisia tabaci. Pertama kali ditemukannya kutu kebul pada tanaman kacang tanah tahun 1986 di rumah kaca florida. Kutu kebulmerupakan hama yang bersifat polifag dapat bertahan hidup pada tanaman pangan, hias dan sayuran, tidak terkecuali kacang tanah. Informasi mengenai kutu kebul yang menyebabkan kerugian pada kacang tanah pertama kali ditemukan di India pada tahun 1986 dan berikutnya dilaporkan di Florida pada tahun 
1987(Lynch dan Simmons, 1993; McAuslane et al., 1995). Pada tahun 1988 dan 1989 kehilangan hasil kacang tanah di Florida akibat serangan kutu kebul mencapai 459,5 kg/ha. Pada tahun 1991 kutu kebul menyebabkan kehilangan hasil setara dengan 5.000.000.000 (Perring et al.,1993). Langkah selanjutnya para pemulia di Flourida merakit varietas kacang tanah tahan kutu kebul (McAuslane et al., 1995). Di Indonesia, gagal panen kacang tanah akibat serangan kutu kebul terjadidi kebun percobaan (KP) Muneng Probolinggo Jawa Timur pada tahun 2012 dan 2015 (Inayati dan Marwoto 2012; Kasno 2015).

Kutu kebul merupakan salah satu hama pengisap cairan yang berada didalam lapisan floem. Hal itu mengakibatkan kerusakan langsung dan kerusakan tidak langsung pada tanaman kacang tanah. Kerusakan langsung berupa timbulnya embun jelaga yang tumbuh pada sisa sekresi kutu kebul. Disamping itu, keruskan tidak langsung kutu kebul berperan sebagai vector virus (H.K. et al., 2014; Wang et al., 2017). Akibat embun jelaga dapat mempengaruhi fisiologi tanaman (Cameron et al., 2014). Keberadaan embun jelaga pada daun dapat berupa sebagian kecil ataupun menyeluruh menutupi permukaan daun. Embun jelaga pada daun menyebabkan terhalangnya sinar matahari masuk kedalam daun. Sinar matahari diperlukan tanaman sebagai sumber energi untuk menjalankan dua tahapan rekasi fotosintetis yaitu reaksi terang dan siklus calvin (Yustiningsih, 2019). Apabila sinar matahari yang diperlukan daun untuk melangsungkan proses fotosintentis berkurang, maka dapat mempengaruhi pertumbuhan tanaman. Penelitian ini bertujuan untuk mengetahui keragaan tanaman kacang tanah setelah terinfeksi kutu kebul.

\section{METODE PENELITIAN}

\section{Bahan}

Bahan yang digunakan dalam penelitian ini antara lain 10 genotipe kacang tanah (Tabel 1) dan imago kutu kebul.

Penelitian dilaksanakan di rumah kaca Balai Penelitian Aneka Kacang dan Umbi Malang pada bulan Nopember 2019 hingga Februari 2020. Materi yang digunakan terdiri dari 10 genotipe kacang tanah. Penelitian disusun menggunakan rancangan acak kelompok (RAK) 10 perlakuan, dan diulang sebanyak tiga kali.

Tahap awal penelitian adalah menanam tanaman kapas yang digunakan sebagai tempat perbanyakan serangga uji. Biji kapas ditanam dalam polybag yang berisi $7 \mathrm{~kg}$ campuran tanah dan pupuk kandang (6:1). Masing-masing polybag ditanami 5-8 biji kapas. Tanaman kapas diletakkan didalam rumah kasa hitam. Pemeliharan tanaman kapas meliputi pemupukan dengan menggunakan NPK Mutiara 1 g/polybag dan juga dilakukan penyiraman bilan tanah sudah mulai mongering. Pada umur 15 hari setelah tanam (HST), tanaman kapas diinfestasi imago kutu kebul. Imago kutu kebul ditangkapdari tanaman kedelai yang berada di kebun percobaan (KP) Kendalpayak Malang. Imago dibiarkan berkembang ditanaman kapas hingga menghasilkan generasi baru.

Tabel 1. Genotipe Kacang Tanah yang Digunakan Sebagai Bahan Tanam dalam Penelitian

\begin{tabular}{lc}
\hline Genotipe & Tipe pertumbuhan \\
\hline Tl/T3-12-C-174-85-30-20 & Spanish \\
GH5-116-21 & Spanish \\
Tk1/Mcn-12-C-2-11-146-231 & Spanish \\
Tk1/Mcn-12-C-2-5-140-163 & Spanish \\
Tasia 1 & Spanish \\
Tasia 2 & Spanish \\
Talam 1 & Spanish \\
Takar 2 & Spanish \\
Domba & Valencia \\
Singa & Valencia \\
\hline
\end{tabular}

Tahapan selanjutnya adalah menanam benih kacang tanah pada polybag yang berisi $7 \mathrm{~kg}$ campuran tanah dan pupuk kandang (6:1). Pada masing-masing polybag ditanam sejumlah 2-3 biji kacang tanah. Pada umur 15 hari, dilakukan penjarangan tanaman dan disisakan 1 tanaman/polibag. Pemeliharan tanaman meliputi penyiraman yang dilakukan bila kondisi tanah kering, peyiangan gulma secara mekanik dan aplikasi fungisida bila ditemukan penyakit. Untuk pengendalian hama selain kutu kebul dilakukan secara mekanik. Selanjutnya pada umur 45 HST tanaman kacang tanah diinfestasi imago kutu kebul yang berasal dari hasil perbanyakan.

Pengamatan dilakukan pada umur 70 HST meliputi populasi total kutu kebul, intensitas embun jelaga. Dan pada saat panen diamati parameter pertumbuhan meliputi jumlah bunga, jumlah ginofor, jumlah akar, panjang akar, tinggi tanaman, dan jumlah cabang. Parameter komponen hasil meliputi jumlah polong, berat polong, jumlah biji, dan berat biji. 
Data hasil pengamatan dianalisis menggunakan anova, dan apabila berbeda nyata dilanjutkan uj Duncan. Selain itu, dilakukan uji korelasi.

\section{HASIL DAN PEMBAHASAN}

Populasi kutu kebul pada umur 70 HST tersaji pada Tabel 2. Populasi tersebut mengakibatkan timbulnya embun jelaga pada daun kacang tanah dengan intensitas penutupan daun berbeda pada masing-masing genotipe.

Tabel 2. Populasi Kutu Kembul Serta Intensitas Embun Jelaga yang Ditimbulkan Akibat Adanya Populasi.

\begin{tabular}{lcc}
\hline \multicolumn{1}{c}{ Genotipe kacang tanah } & Populasi kutu kebul & Intensitas embun jelaga (\%) \\
\hline Tl/T3-12-C-174-85-30-20 & $6,47 \mathrm{dc}$ & $15,24 \mathrm{~b}$ \\
GH5-116-21 & $8,70 \mathrm{bcd}$ & $13,08 \mathrm{~b}$ \\
Tk1/Mcn-12-C-2-11-146-231 & $5,50 \mathrm{dc}$ & $15,55 \mathrm{~b}$ \\
Tk1/Mcn-12-C-2-5-140-163 & $8,64 \mathrm{dc}$ & $10,80 \mathrm{~b}$ \\
Tasia 1 & $6,64 \mathrm{dc}$ & $14,54 \mathrm{~b}$ \\
Tasia 2 & $5,12 \mathrm{dc}$ & $14,36 \mathrm{~b}$ \\
Talam 1 & $4,52 \mathrm{c}$ & $23,37 \mathrm{a}$ \\
Takar 2 & $23,04 \mathrm{ab}$ & $23,12 \mathrm{a}$ \\
Domba & $13,57 \mathrm{abc}$ & $25,87 \mathrm{a}$ \\
Singa & $27,57 \mathrm{a}$ & $25,45 \mathrm{a}$ \\
\hline Rata-rata & 10,98 & 18,14 \\
Pengaruh genotipe & $* *$ & $* *$ \\
\hline
\end{tabular}

Dari 10 genotipe kacang tanah yang diuji, populasi kutu kebul tertinggi ditemukan pada varietas domba (27,57/daun tetrafoliat). Sedangkan opulasi terendah ditemukan pada varietas Talam 1 (4,52/daun tetrafoliat). Rata-rata populasi kutu kebul pada 10 genotipe sebesar 10,98 dan menunjukkan berbeda sangat nyata antar genotipe dengan nilai BNT 1,48. Populai yang ada menimbulkan embun jelaga yang menutupi daun kacang tanah. Rata-rata keseluruhan embun jelaga sebesar 18,14 \%. Intensitas penutupan daun paling banyak terlihat pada daun varietas Domba sebesar 25,87\% selanjutnya varietas Singa sebesar $25,45 \%$. Sedangkan penutupan daun akibat embun jelaga yang paling kecil berada pada genotipe Tk1/Mcn-12-C-2-5-140-163 (10,80\%) (Tabel 2).

Tabel 3. Jumlah bunga, jumlah ginofor, jumlah akar, panjang akar,tinggi tanaman, dan jumlah cabang genotipe kacang tanah

\begin{tabular}{lllllll}
\hline \multicolumn{1}{c}{ Genotipe } & $\begin{array}{c}\text { Jumlah } \\
\text { bunga }\end{array}$ & $\begin{array}{c}\text { Jumlah } \\
\text { ginofor }\end{array}$ & $\begin{array}{c}\text { Jumlah } \\
\text { akar }\end{array}$ & $\begin{array}{c}\text { Panjang } \\
\text { akar }\end{array}$ & $\begin{array}{c}\text { Tinggi } \\
\text { tanaman }\end{array}$ & $\begin{array}{c}\text { Jumlah } \\
\text { cabang }\end{array}$ \\
\hline T1/T3-12-C-174-85-30-20 & 16,36 & $10,76 \mathrm{~cd}$ & $37,22 \mathrm{abc}$ & $12,26 \mathrm{a}$ & 38,76 & $5.38 \mathrm{abc}$ \\
GH5-116-21 & 15,53 & $17,66 \mathrm{abc}$ & $33,16 \mathrm{~cd}$ & $8,59 \mathrm{~b}$ & 37,49 & $6.09 \mathrm{a}$ \\
Tk1/Mcn-12-C-2-11-146-231 & 16,00 & $12,71 \mathrm{bcd}$ & $42,12 \mathrm{a}$ & $11,78 \mathrm{ab}$ & 34,32 & $6.04 \mathrm{ab}$ \\
Tk1/Mcn-12-C-2-5-140-163 & 19,13 & $14,09 \mathrm{bcd}$ & $40,24 \mathrm{ab}$ & $11,67 \mathrm{ab}$ & 35,23 & $6.05 \mathrm{ab}$ \\
Tasia 1 & 16,56 & $9,38 \mathrm{~d}$ & $35,14 \mathrm{~cd}$ & $12,12 \mathrm{a}$ & 39,19 & $5.19 \mathrm{c}$ \\
Tasia 2 & 16,56 & $12,38 \mathrm{bcd}$ & $34,14 \mathrm{~cd}$ & $12,32 \mathrm{a}$ & 33,33 & $5.33 \mathrm{bc}$ \\
Talam 1 & 16,20 & $13,73 \mathrm{bcd}$ & $36,31 \mathrm{bcd}$ & $13,44 \mathrm{a}$ & 35,65 & $5.47 \mathrm{abc}$ \\
Takar 2 & 15,40 & $19,14 \mathrm{ab}$ & $32,22 \mathrm{~d}$ & $8,67 \mathrm{~b}$ & 36,87 & $4.09 \mathrm{~d}$ \\
Domba & 12,76 & $18,71 \mathrm{ab}$ & $34,63 \mathrm{~cd}$ & $13,20 \mathrm{a}$ & 34,19 & $4.09 \mathrm{~d}$ \\
Singa & 15,80 & $21,04 \mathrm{a}$ & $37,22 \mathrm{bc}$ & $12,91 \mathrm{a}$ & 38,02 & $4.00 \mathrm{~d}$ \\
\hline Rata-rata & 15,85 & 14,91 & 36,28 & 11,69 & 36,30 & 5,17 \\
& $0,21^{\mathrm{ns}}$ & $0,02^{*}$ & $0,003^{* *}$ & $0,032^{*}$ & $0,532^{\mathrm{ns}}$ & $0,000^{* *}$ \\
\hline
\end{tabular}

Pengaruh langsung adanya populasi kutu kebul pada tanaman kacang tanah menyebabkan timbulnya embun jelaga pada daun. Embun jelaga merupakan sisa cairan getah floem tidak terasimilasi akibat hisapan stilet kutu kebul. Pada umumnya embun jelaga berwarna hitam. yang berasal dari sisa makanan yang dihisap. Kutu kebul mengandung gula, asam organik, asam amino dan beberapa senyawa lipid (Roopa et al., 2016). Selain itu, embun jelaga dapat menularkan lebih dari 100 patogen virus terutama spesies Begomovirus (Cameron et al., 2014; Roopa et al., 2014).

Jumlah bunga pada masing-masing genotipe kacang tanah tidak berbeda nyata antar genotipe dengan nilai rata-rata sebesar 15,85/ 1 rumpun. Dalam tahap perkembangannya selanjutnya, bunga membentuk ginofor. Jumlah ginoforyang terbentuk pada masing-masing genotipe berbeda nyata dengan nilai rata-rata sebesar 14,91/1 rumpun. Jumlah ginofor paling tinggi ditemukan pada varietas Singa sebesar 21,04 diikuti Takar 2 $(19,14)$ dan Domba $(18,71)$. Sedangkan ginofor paling sedikit ditemukan pada varietas Tasia $1(9,38)$ dan 
disusul Tl/T3-12-C-174-85-30-20 (10,76). Rata-rata jumlah akar menunjukkan nilai 36,28 dan berbeda sangat nyata antar genotipe. Jumlah akar tertinggi ditemukan pada genotipe Tk1/Mcn-12-C-2-11-146-231 (42,12) disusul dengan Tk1/Mcn-12-C-2-5-140-163 (40,24). Sedangkan jumlah akar paling sedikit dijumpai pada genotipe Takar 2 (32,22). Untuk rata-rata panjang akar sebesar 11,69 danpanjang akar dari genotipe GH5-11621 dan Takar 2 lebih pendek dibandingkan sebagian besar genotipe lain dengan nilai 8,67 dan 8,69 cm. Tinggi tanaman kacang tanah secara garis besar sama dengan nilai rata-rata sebesar $36,30 \mathrm{~cm}$. sedangkan dari jumlah cabang menunjukkan rata-rata keseluruhan sebesar 5,17dengan cabang tertinggi ditemukan pada genotipe GH5116-21 dan cabang paling sedikit pada varietas Takar 2, Domba dan Singa (Tabel 3).

Tabel 4. Korelasi antara intensitas embun jelaga dengan parameter pertumbuhan kacang tanah

\begin{tabular}{cccccccc}
\hline Komponen & EJ & JB & JG & JA & PA & TT & JC \\
\hline EJ & 1,00 & $-0,68^{*}$ & $0,64^{*}$ & 0,61 & $0,84^{* *}$ & $-0,03$ & $-0,83^{* *}$ \\
JB & & 1,00 & $-0,47$ & $-0,19$ & $-0,46$ & 0,10 & 0,59 \\
JG & & 1,00 & 0,35 & $0,69^{*}$ & $-0,06$ & $-0,60$ \\
JA & & & 1,00 & $0,83^{* *}$ & $-0,36$ & $-0,62$ \\
PA & & & & 1,00 & $-0,16$ & $-0,82^{* *}$ \\
TT & & & & & 1,00 & $-0,13$ \\
JC & & & & & & 1,00 \\
\hline
\end{tabular}

Ket : EJ = embun jelaga, JB =jumlah bunga, $\mathrm{JG}=$ jumlah ginofor, $\mathrm{JA}=$ jumlah akar, $\mathrm{PA}=$ panjang akar, $\mathrm{TT}=$ tinggi tanaman, $\mathrm{JC}=$ jumlah cabang

Berdasarkan tabel korelasi embun jelaga yang ada pada daun berkorelasi negative dengan jumlah bunga dengan nilai sebesar $-0,68^{*}$, berkorelasi positif dengan panjang akar dengan nilai sebesar $0,84^{* *}$ dan berkorelasi negatif dengan jumlah cabang dengan nilai $-0,83^{* *}$ (Tabel 4$)$.

Intensitas embun jelaga berkorelasi negatif dengan jumlah bunga artinya adalah bahwa semakin tinggi intensitas embun jelaga maka jumlah bunga semakin sedikit. Begitu juga dengan jumlah cabang yang berkorelasi negatif dengan embun jelaga. Hal ini disebabkan karena perkembangan vegetatif tanaman dipengaruhi oleh kualitas dan kuantitas sinar matahari (Board, 2000). Selanjutnya sinar matahari akan diterima dan disalurkan ke kloroplast oleh daun. Kloroplast lebih banyak menyerap sinar merah dan biru (Terashima et al., 2011). Dengan demikain apabila permukaan daun terhalang oleh embun jelaga yang ada makan kualitas dan kuantitas sinar yang diterima daun akan lebih sedikit dibandingkan dengan daun normal tanpa tertutup embun jelaga. Berbeda dengan dua hal tersebut,embun jelaga berkorelasi positif dengan panjang akar, artinya bahwa semakin tinggi embun jelaga maka akar semakin panjang. Hal ini dipengaruhi karena terbentuknya reaktif oksigen spesies (ROS) yang disebabkan karena cekaman yang terjadi pada tanaman. Meningkatnya ROS menyebabkan kerusakan oksidatif dan kematian sel. Jaringan sinyal ROS menunjukkan adanya komunikasi silang dengan jaringan hormonal, sehingga memungkinkan tanaman untuk mengatur proses perkembangan dan merespon toleransi terhadap cekaman biotik atau abiotik. Komunikasi silang antara ROS dengan hormon pada akar selanjutnya menjadi sinyal ektrinsik dan menyebabkan terbentuknya root apical meristem (RAM) (Tognetti et al., 2012). Hal itu juga didukung dengan korelasi positif antara panjang akar dan jumlah akar.

Parameter komponen hasil dilihat dari jumlah polong dan berat polong yang dihasilkan masing-masing genotipe, jumlah biji total, presentase biji normal dan berat kering biji. Polong kacang tanah dipisahkan antara polong isi dan polong hampa. Infestasi kutu kebul memberikan pengaruh nyata pada jumlah polong isi masingmasing genotipe kacang tanah. Infestasi tersebut juga berpengaruh nyata terhadap jumlah polong hampa, berat polong isi dan berat polong hampa pada masing-masing genotipe.

Genotipe Tk1/Mcn-12-C-2-5-140-163 menunjukkan rata-rata jumlah polong paling tinggi sebesar 18,18 polong/tanaman, sedangkan rata-rata jumlah polong terendah ditunjukkan pada genotipe Singa $(11,52)$ dan Domba (10,38) polong/tanaman. Nilai rata-rata jumlah polong sebesar 15,11.

Rata-rata jumlah polong hampa tertinggi ditunjukkan oleh genotipe GH5-116-21 sebesar 7,19 polong/tanaman. Lima genotipe kacang tanah menunjukkan rata-rata jumlah polongnya rendah. Kelima genotipe tersebut antara lain Tl/T3-12-C-174-85-30-20, Tk1/Mcn-12-C-2-5-140-163, Tasia 1, Tasia 2, dan Talam 1 (Tabel 5).

Berat polong isi dan hampa berbanding lurus dengan jumlah polong isi. Rata-rata berat polong isi tinggi ditunjukkan genotipe Tl/T3-12-C-174-85-30-20 (19,34 gr/tanaman) dan Tk1/Mcn-12-C-2-5-140-163 (18,89 gr/tanaman) dengan nilai rata-rata keseluruhan sebesar 15,61. Genotipe Domba menunjukkan berat polong isi paling rendah sebesar 11,55 gr/tanaman. Sedangkan berat polong hampa paling tinggi ditunjukkan pada genotipe Singa (1,13 gr/tanaman) dengan nilai rata-rata keseluruhan sebesar 0,47 (Tabel 5).

Tabel 6. Rata-rata jumlah polong dan berat polong kering genotipe kacang tanah setelah diinfestasi kutu kebul

\begin{tabular}{lll}
\hline Genotipe & Jumlah polong & Berat polong/tan (gr)
\end{tabular}




\begin{tabular}{|c|c|c|c|c|}
\hline & Isi & Hampa & Isi & Hampa \\
\hline Tl/T3-12-C-174-85-30-20 & $17,81 \mathrm{ab}$ & $2,85 \mathrm{c}$ & $19,34 \mathrm{a}$ & $0,33 \mathrm{~b}$ \\
\hline GH5-116-21 & $14,66 \mathrm{~d}$ & $7,19 \mathrm{a}$ & $12,87 \mathrm{dc}$ & $0,89 \mathrm{a}$ \\
\hline Tk1/Mcn-12-C-2-11-146-231 & $17,19 \mathrm{abc}$ & $4,00 \mathrm{bc}$ & $17,96 \mathrm{ab}$ & $0,38 \mathrm{~b}$ \\
\hline Tk1/Mcn-12-C-2-5-140-163 & $18,18 \mathrm{a}$ & $3,24 \mathrm{c}$ & 18,89 a & $0,34 \mathrm{~b}$ \\
\hline Tasia 1 & $15,04 \mathrm{~cd}$ & $2,76 \mathrm{c}$ & $16,54 a b$ & $0,29 \mathrm{~b}$ \\
\hline Tasia 2 & $16,00 \mathrm{abcd}$ & $2,24 \mathrm{c}$ & $16,78 \mathrm{ab}$ & $0,20 \mathrm{~b}$ \\
\hline Talam 1 & $15,57 \mathrm{bcd}$ & $3,05 \mathrm{c}$ & $15,66 \mathrm{bc}$ & $0,25 \mathrm{~b}$ \\
\hline Takar 2 & $14,76 \mathrm{~cd}$ & $3,86 \mathrm{bc}$ & $13,34 \mathrm{dc}$ & $0,28 \mathrm{~b}$ \\
\hline Domba & 10,38 e & $5,57 \mathrm{ab}$ & $11,55 \mathrm{~d}$ & $0,63 a b$ \\
\hline Singa & $11,52 \mathrm{e}$ & $5,47 \mathrm{ab}$ & $13,18 \mathrm{dc}$ & $1,13 \mathrm{a}$ \\
\hline Rata-rata & 15,11 & 4,02 & 15,61 & 0,47 \\
\hline Pengaruhgenotipe & $2,49 * *$ & $0,43 * *$ & $3,17 * *$ & $0,50 * *$ \\
\hline
\end{tabular}

Ket: Angka-angka yang didampingi huruf yang sama pada kolom yang sama berarti tidak berbeda pada uji beda nyata terkecil pada taraf $5 \%$.

$*, * *$, tn $=$ berbeda nyata pada $\mathrm{p}=0,05$, berbeda sangat nyata pada $\mathrm{p}=0,01$, tidak berbeda nyata

$\mathrm{BNT}=$ Beda NyataTerkecil

$\mathrm{JmlP}=$ Jumlah polong, BrtP = berat polong

Infestasi kutu kebul tidak berpengaruh terhadap jumlah biji masing-masing genotipe. Hal tersebut terlihat hasil anova pada Tabel 24 tidak berbeda nyata. Rata-rata jumlah biji total sebesar 28,24 (Tabel 7).

Persentase biji normal merupakan pemisahan antara biji normal dengan biji keriput. Infestasi kutu kebul yang dilakukan berpengaruh sangat nyata terhadap jumlah biji normal antar genotipe dengan nilai rata-rata keseluruhan 84,99. Genotipe Tasia 1 menunjukkan presentase biji normal tertinggi dengan nilai sebesar 92,16\%. Genotipe GH5-116-21 menunjukkan persentase biji normal terendah dari semua genotipe yang diuji dengan nilai $69,42 \%$ (Tabel 7).

Memiliki pola yang sama dengan presentase biji normal, berat biji kering genotipe kacang tanah setelah diinfestasi kutu kebul juga menunjukkan berbeda sangat nyata pada setiap genotipe dengan nilai rata-rata sebesar 11,37. Berat biji kering paling tinggi ditunjukkan pada genotipe Tk1/Mcn-12-C-2-11-146-231 (13,43 g). Berat biji paling rendah ditunjukkan genotipe Takar $2(9,20 \mathrm{~g})$ diikuti Domba $(8,89)$ (Tabel 7).

Indeks panen genotipe kacang tanah akibat infestasi kutu kebul menunjukkan berbeda sangat nyata antar genotipe dengan nilai rata-rata sebesar 0,40. Indeks panen tinggi ditunjukkan oleh dua genotipe yaitu Tk1/Mcn12-C-2-11-146-231 (0,46) dan Tl/T3-12-C-174-85-30-20 (0,45). Dua genotipe GH5-116-21 dan Singa menunjukkan indeks panen paling rendah yaitu sebesar 0,37 (Tabel 7).

Tabel 7. Rata-rata jumlah biji, presentase biji normal dan berat biji kering genotipe kacang tanah setelah diinfestasi kutu kebul

\begin{tabular}{lcclc}
\hline \multicolumn{1}{c}{ Genotipe } & Jumlah biji & $\begin{array}{c}\text { Persentase biji } \\
\text { normal } \\
(\%)\end{array}$ & $\begin{array}{c}\text { Berat biji/tan } \\
(\mathrm{g})\end{array}$ & IP \\
\hline Tl/T3-12-C-174-85-30-20 & 32,09 & $88,35 \mathrm{abcd}$ & $12,16 \mathrm{abc}$ & $0,45 \mathrm{a}$ \\
GH5-116-21 & 25,85 & $69,42 \mathrm{e}$ & $11,42 \mathrm{abc}$ & $0,37 \mathrm{c}$ \\
Tk1/Mcn-12-C-2-11-146-231 & 27,62 & $87,56 \mathrm{abcd}$ & $13,43 \mathrm{a}$ & $0,46 \mathrm{a}$ \\
Tk1/Mcn-12-C-2-5-140-163 & 30,62 & $82,27 \mathrm{~d}$ & $12,94 \mathrm{ab}$ & $0,44 \mathrm{ab}$ \\
Tasia 1 & 27,09 & $92,16 \mathrm{a}$ & $12,20 \mathrm{abc}$ & $0,41 \mathrm{abc}$ \\
Tasia 2 & 29,33 & $90,01 \mathrm{ab}$ & $11,81 \mathrm{abc}$ & $0,44 \mathrm{ab}$ \\
Talam 1 & 27,81 & $89,34 \mathrm{abc}$ & $10,74 \mathrm{~cd}$ & $0,38 \mathrm{c}$ \\
Takar 2 & 26,04 & $82,39 \mathrm{~d}$ & $9,20 \mathrm{~d}$ & $0,38 \mathrm{c}$ \\
Domba & 27,42 & $85,37 \mathrm{bcd}$ & $8,89 \mathrm{~d}$ & $0,39 \mathrm{bc}$ \\
Singa & 28,57 & $83,02 \mathrm{~cd}$ & $10,98 \mathrm{bcd}$ & $0,37 \mathrm{c}$ \\
\hline Rata-rata & 28,24 & 84,99 & 11,37 & 0,40 \\
Pengaruhgenotipe & tn & $6,45 * *$ & $2,10 * *$ & $0,05 * *$ \\
\hline
\end{tabular}

Ket: Angka-angka yang didampingi huruf yang sama pada kolom yang sama berarti tidak berbeda pada uji beda nyata terkecil pada taraf $5 \%$.

*,**,tn =berbeda nyata pada $\mathrm{p}=0,05$, berbeda sangat nyata pada $\mathrm{p}=0,01$, tidak berbeda nyata $\mathrm{BNT}=$ Beda NyataTerkecil

$\mathrm{JmlBj}=$ jumlah biji total, $\mathrm{Pbj}=$ presentase biji normal, $\mathrm{BrtBj}=$ Berat biji normal, $\mathrm{IP}=$ Indeks panen

Populasi kutu kebul dan embun jelaga mempengaruhi komponen hasil kacang tanah. Komponen hasil tersebut antara lain jumlah polong isi, berat polong isi, dan berat biji kering. Populasi kutu kebul berkorelasi 
negatif dengan jumlah polong isi yang dihasilkan dengan nilai $r=-0,64$. Hal yang sama terjadi pada berat polong isi, korelasi negatif terjadi antara populasi kutu kebul dengan berat polong isi dengan nilai $r=-0,68$. Dan korelasi negatif juga terjadi antara populasi kutu kebul dengan berat biji kering dengan nilai $r=-0,84($ Tabel 8$)$. Hal ini berarti bahwa semakin tinggi populasi kutu kebul maka akan mengurangi jumlah polong isi yang dihasilkan, dan berpengaruh ke berat polong isi serta jumlah biji yang dihasilkan.

Sama halnya dengan populasi, embun jelaga juga berkorelasi negatif dengan jumlah polong isi, berat kering polong isi dan berat biji kering dengan nilai $r$ berturut-turut sebesar $-0,76,-0,68$ dan $-0,80$. Hal ini berarti bahwa semakin tinggi intensitas embun jelaga pada daun kacang tanah maka akan menurunkan jumlah polong yang dihasilkan, menurunkan berat kering polong serta menurunkan jumlah biji yang dihasilkan. Selain itu, intensitas embun jelaga juga berkorelasi negatif dengan indeks panen dengan nilai $r=-0,61$ (Tabel 8). Hal ini berarti bawa embun jelaga pada daun mempengaruhi distribusi asimilat ke dalam polong. Semakin tinggi intensitas embun jelaga makan semakin berkurang asimilat yang didistribusikan kedalam polong.

Jumlah polong isi berkorelasi positif dengan berat kering polong isi, berat biji kering dan indeks panen dengan nilai $r$ berturut-turut sebesar 0,89; 0,74; dan 0,76 (Tabel 8). Hal ini berarti bahwa semakin tinggi jumlah polong isi, maka semakin tinggi pula berat biji kering yang dihasilkan. Hal itu diakibatkan karena pendistribusian asimilat ke polong tinggi.

Jumlah polong hampa berkorelasi negatif dengan berat kering polong isi dengan nilai $r=-0,72$. Jumlah polong hampa berkorelasi positif dengan berat kering polong hampa dengan nilai $r=0,88$, berkorelasi negatif dengan presentasi biji normal dengan nilai $r=-0,81$. Serta berkorelasi negatif dengan indeks panen dengan nilai $\mathrm{r}=-0,65$ (Tabel 8). Hal ini berarti bahwa semakin tinggi jumlah polong hampa, maka berat kering polong hampa semakin tinggi pula. Semakin tinggi jumlah polong hampa, jumlah biji normalnya sedikit. Dan semakin tinggi polong hampa, maka indeks panennya semakin rendah diakibatkan asimilat tidak terdistribusi dengan baik.

Semakin tinggi jumlah biji normal, maka semakin tinggi pula berat biji kering. Hal ini dibuktikan dengan adanya korelasi positif antara presentase biji normal dengan berat biji kering dengan nilai $\mathrm{r}=0,68$. Berat biji kering berkorelasi positif dengan indeks panen dengan nilai $\mathrm{r}=0,68$ (Tabel 8). Hal ini dikarenakan pendistribusian asimilat ke polong cukup tinggi.

Pembentukan polong merupakan periode yang sangat peka terhadap cekaman biotik maupun abiotik. Dalam pembentukan polong, selain tanaman membutuhkan tanah yang lembab, tanaman juga membutuhkan nutrisi. Kedatangan kutu kebul serta perkembangannya di tanaman berdampak terhadap berkurangnya kandungan nutrisi daun. Hal itu disebabkan karena kutu kebul menghisap cairan daun yang merupakan hasil fotosintetis pada jaringan floem. Kutu kebul menggunakan stiletnya untuk menusuk kutikula, epidermis, mesofil, dan akan berhenti pada jaringan floem. Jaringan floem merupakan bagian dalam tanaman yang mengandung hasil fotosintetis antara lain gula dan karbon (Slewinski et al., 2013; Tsueda et al., 2014). Nimfa akan menghisap cairan secara terus menerus selama 21-30 hari (Wang et al., 2017). Karena hal tersebut, maka hasil fotosintetis tidak dapat terdistribusi ke seluruh bagaian tanaman sehingga mengakibatkan pertumbuhan tanaman terganggu. Selain hal itu, akibat adanya penutupan daun oleh embun jelaga yang tumbuh akibat sekresi kutu kebul, maka mengganggu masuknya cahaya yang masuk ke daun, sehingga berdampak pada fotosintetis berjalan tidak maksimal. Luas area permukaan daun yang kurang maksimal akan mempengaruhi penguraian C02, sehingga menyebabkan fotosintetis berjalan lambat (Terashima et al., 2011). Hal itu juga diperkuat dengan nilai indeks panen rendah. Pada genotipe kacang tanah yang hasil bijinya rendah berbanding lurus dengan indeks panen yang rendah. Indeks panen merupakan terdistribusinya hasil asimilat ke seluruh bagian tanaman. Sehingga indeks panen rendah menandakan bahwa hasil asimilat yang didistribusikan ke seluruh bagian tanaman rendah.

Tabel 8. Korelasi antara populasi kutu kebul, embun jelaga dan komponen hasil

\begin{tabular}{|c|c|c|c|c|c|c|c|c|c|c|}
\hline Variabel & Pop & $\mathrm{EJ}$ & $\begin{array}{l}\text { JmlP } \\
\text { isi }\end{array}$ & $\begin{array}{c}\text { JmlP } \\
\text { hampa }\end{array}$ & BrtP isi & $\begin{array}{c}\text { BrtP } \\
\text { hampa }\end{array}$ & $\mathrm{JmlBj}$ & PBJ & $\mathrm{BrtBj}$ & IP \\
\hline Pop & 1,00 & $0,72 *$ & $-0,64 *$ & $0,36^{\mathrm{tn}}$ & $-0,68 *$ & $0,24^{\mathrm{tn}}$ & $-0,35^{\mathrm{tn}}$ & $-0,16^{\mathrm{tn}}$ & $-0,84 * *$ & $-0,48^{\mathrm{tn}}$ \\
\hline EJ & & 1,00 & $-0,76^{* *}$ & $0,29^{\mathrm{tn}}$ & $-0,68^{*}$ & $0,30^{\mathrm{tn}}$ & $-0,32^{\text {tn }}$ & $0,10^{\mathrm{tn}}$ & $-0,80 * *$ & $-0,61 *$ \\
\hline $\mathrm{JmlP}$ isi & & & 1,00 & $-0,60^{\mathrm{tn}}$ & $0,89 * *$ & $0,30^{\text {tn }}$ & $0,48^{\mathrm{tn}}$ & $0,17^{\mathrm{tn}}$ & $0,74^{*}$ & $0,76^{*}$ \\
\hline $\begin{array}{l}\text { JmlP } \\
\text { hampa }\end{array}$ & & & & 1,00 & $-0,72 *$ & $0,88 * *$ & $-0,51^{\text {tn }}$ & $-0,81 * *$ & $-0,21^{\text {tn }}$ & $-0,65^{*}$ \\
\hline $\mathrm{BrtP}$ isi & & & & & 1,00 & $-0,61 *$ & $0,72 *$ & $0,46^{\mathrm{tn}}$ & $0,82 * *$ & $0,85 * *$ \\
\hline $\begin{array}{l}\text { BrtP } \\
\text { hampa }\end{array}$ & & & & & & 1,00 & $-0,25^{\text {tn }}$ & $-0,66^{*}$ & $-0,21^{\mathrm{tn}}$ & $-0,67 *$ \\
\hline $\mathrm{JmlBj}$ & & & & & & & 1,00 & $0,36^{\mathrm{tn}}$ & $0,45^{\mathrm{tn}}$ & $0,55^{\mathrm{tn}}$ \\
\hline
\end{tabular}

Proceedings homepage: https://conferenceproceedings.ump.ac.id/index.php/pspfs/issue/view/9 


\begin{tabular}{|c|c|c|c|}
\hline PBJ & 1,00 & $0,68 *$ & $0,49^{\mathrm{tn}}$ \\
\hline $\mathrm{BrtBj}$ & & 1,00 & $0,68 *$ \\
\hline IP & & & 1,00 \\
\hline
\end{tabular}

Keterangan :

$*, * *$, tn $=$ berbeda nyata pada $\mathrm{p}=0,05$, berbeda sangat nyata pada $\mathrm{p}=0,01$, tidak berbeda nyata

Pop = populasi kutu kebul, EJ = embun jelaga, JmlP isi = jumlah polong isi, JmlP hampa = jumlah polong hampa, BrtP isi = berat polong isi, $\mathrm{BrtP}$ hampa $=$ berat polong hampa, $\mathrm{JmlBj}=$ jumlah biji, $\mathrm{PBj}=$ presentase biji normal, $\mathrm{BrtBj}=$ berat biji keting, $\mathrm{IP}=$ indeks panen.

\section{KESIMPULAN}

Keragaan kacang tanah setelah terserang kutu kebul antara lain jumlah bunga dan jumlah cabang sedikit, serta jumlah polong isi, berat polong isi, berat biji kering dan indeks panen menunjukkan nilai yang rendah.

\section{DAFTAR PUSTAKA}

Board, J. (2000). Light Interception Efficiency and Light Quality Affect Yield Compensation of Soybean at Low Plant Populations. Crop Science, 40(5), 1285-1294.https://doi.org/https://doi.org/10.2135/cropsci2000. 4051285x.

B.R. Lassiter, D.L. Jordan, G.G. Wilkerson , B.B. Shew, dan R.L. Brandenburg. 2016. Influence of Planting Pattern on Pest Management in Virginia Market Type Peanut (Arachis hypogaea L.). Peanut science Journal 43: 59-66.

Cameron, R., Lang, E. B., \& Alvarez, J. M. (2014). Use of honeydew production to determine reduction in feeding by bemisia tabaci (Hemiptera: Aleyrodidae) adults when exposed to cyantraniliprole and imidacloprid treatments. Journal of Economic Entomology, 107(2), 546-550. https://doi.org/10.1603/ EC13369.

H.K., R., K.B., R., R., A., Mahmood, R., \& N.K., K. K. (2014). Isolation and identification of culturable bacteria from honeydew of whitefly, Bemisia tabaci (G.) (Hemiptera: Aleyrodidae). Meta Gene, 2, 114122. https://doi.org/https:// doi.org/10.1016/j.mgene.2013.11.002

Lynch R.E., A.M Simmons. 1993. Distribution of Immatures and Monitoring of Adult Sweetpotato Whitefly, Bemisia tabaci (Gennadius) (Homoptera: Aleyrodidae), in Peanut, Arachis hypogaea. Environ. Entomol. 22:375-380.

McAuslane H.J., D.A Knauft, dan F A Johnson. 1995. Evaluation of Peanut Breeding Lines for Resistance to Silverleaf whitefly (Homoptera: Aleyrodidae). The Florida Entomol. 78:75-81.

Mohammed A. Al-Saleh, Hassan A. Melouk, dan Phillip Mulder. 2007. Reaction of Peanut Cultivars to Tomato Spotted Wilt Virus (TSWV) Under Field Conditions and Their Response to Mechanical Inoculation by TSWV Under Greenhouse Conditions. Peanut science Journal 34:44-52.

Perring, T., A. D. Cooper, R. J. Rodriguez, C. A. Farrar, dan T. S. Bellows JR. 1993. Identification of a whitefly species by genomic and behavioral studies. Science 259: 74-77.

Roopa, H. K., Asokan, R., Krishna Kumar, N. K., Mahmood, R., Bakthavatsalam, N., Uprithi, K., \& Raghavendra, A. (2016). Estimation of sugars and volatiles in the Honeydew of Bemisia tabaci genetic groups Meam-I and Asia-I. Journal of Bioscience and Biotechnology Discovery, 1(4), 66-73. https://doi.org/ 10.31248/jbbd2016.015.

Roopa, H. K., Rebijith, K. B., Asokan, R., Riaz, M., \& Krishna Kumar, N. K. (2014). Isolation and identification of culturable bacteria from honeydew of whitefly, Bemisia tabaci (G.) (Hemiptera: Aleyrodidae). Meta Gene, 2(1), 114-122. https://doi.org/10.1016/j.mgene.2013.11.002.

Slewinski, T., Zhang, C., \& Turgeon, R. (2013). Structural and functional heterogeneity in phloem loading and transport . In Frontiers in Plant Science (Vol. 4, p. 244). https://www.frontiersin.org/article/10.3389/fpls.2013. 00244.

Terashima, I., Hanba, Y. T., Tholen, D., \& Niinemets, Ü. (2011). Leaf Functional Anatomy in Relation to Photosynthesis. Plant Physiology, 155(1), 108 LP - 116. https://doi.org/10.1104/pp.110.165472.

Tognetti, V. B., Mühlenbock, P., \& van Breusegem, F. (2012). Stress homeostasis - the redox and auxin perspective. Plant, Cell and Environment, 35(2), 321-333. https://doi.org/10.1111/j.13653040.2011.02324.x. 
Tsueda, H., Tsuduki, T., \& Tsuchida, K. (2014). Factors that affect the selection of tomato leaflets by two whiteflies, Trialeurodes vaporariorum and Bemisia tabaci (Homoptera: Aleyrodidae). Applied Entomology and Zoology, 49(4), 561-570. https://doi.org/10.1007/s13355-014-0287-6.

Wang, X.-W., Li, P., \& Liu, S.-S. (2017). Whitefly interactions with plants. Current Opinion in Insect Science, 19, 70-75. https://doi.org/https://doi.org/ 10.1016/j.cois.2017.02.001.

W.D. Branch dan T.B. Brenneman. 2015. Stem Rot (White Mold) and Tomato Spotted Wilt Resistance among Peanut Genotypes. Peanut science Journal 42:18-22.

Yustiningsih, M. (2019). Intensitas Cahaya dan Efisiensi Fotosintesis pada Tanaman Naungan dan Tanaman Terpapar Cahaya Langsung. Bio-Edu: Jurnal Pendidikan Biologi, 4(2), 44-49. https://doi.org/10.32938/jbe.v4i2.385. 